\title{
Social movements and the scaling of memory and justice in Bhopal
}

\section{Dr Pawas Bisht}

School of Humanities, Keele University, Keele, United Kingdom

School of Humanities, Keele University, Staffordshire, ST5 5BG, UK

p.bisht@keele.ac.uk

Dr Pawas Bisht is a Lecturer in Media, Communications and Culture at the School of Humanities, Keele University. His research focuses on media and cultural politics with a particular emphasis on the dynamics of social and cultural remembrance, social movements and environmental politics. 


\section{Social movements and the scaling of memory and justice in Bhopal}

This paper examines the politics of scale in the commemorative work undertaken by the International Campaign for Justice in Bhopal (ICJB), a coalition of social movement organisations seeking justice for the victims of the Bhopal Gas Disaster of 1984. The argument traces how the ICJB attempted to contest the localisation of the disaster by the Indian state and the transnational corporations involved. I outline how the disaster, which had been scaled down from an extraordinary global event to a private non-issue, was re-scaled successfully across multiple scales of meaning and regulation through ICJB's mobilisation of the frame of 'second/ongoing poisoning'. This contestation over the scaling of the disaster crucially involved multiple processes of memory-work. Drawing on archival research and ethnographic fieldwork, this paper reveals how the remembrance of the disaster functioned as a key site of the discursive and performative re-framings required to reinstate multi-scalar accountability for the disaster. Overall, the paper establishes the utility of the politics of scale approach in mapping the dynamics of the transnational mobilisations of memory by social movement organisations in pursuit of justice.

Keywords: Politics of Scale; Memory-work; Transnational Memory; Social Movements; Bhopal Disaster

\section{Introduction: contesting the settlement of Bhopal}

The 1984 gas leak in the Indian city of Bhopal, widely considered one of the world's worst industrial disaster, occurred when the poor maintenance of safety systems led to a leak of poisonous gases from a pesticide factory owned by the Union Carbide Corporation (UCC), an American transnational corporation. Nearly 4,000 people died in the immediate aftermath and several thousands more suffered permanent injuries (Muralidhar 2004). After a protracted wrangling over the appropriate legal forum to arbitrate liability, UCC and the Indian state negotiated a full and final settlement for 470 million dollars absolving the corporation of all current and future liabilities (Das 1998; Baxi 2010). This paper examines the process of contesting the settlement and the demanding of continuing liability from the corporation and the state that has been undertaken by one strand of the social movement in Bhopal. I analyse 
the work of the International Campaign for Justice in Bhopal (ICJB), a coalition of gassurvivors' groups, national and international affiliates seeking justice for Bhopal, focussing in particular on their commemorative activities. I will be analysing how ICJB's remembrance of the disaster can be most usefully understood as participating in a politics of scale that seeks to challenge the juridical settlement of Bhopal by redistributing accountability for the disaster relationally across a host of spatial scales: local, national and transnational. In the following sections, I present an account of the discursive and performative strategies adopted by ICJB as they developed a multi-scalar representation of accountability and justice in their memorialization and contested the localization and forgetting of the disaster desired by the state and the corporation.

The account I provide draws on archival materials collected between 2010 and 2017 and ethnographic fieldwork undertaken between 2010 and 2014 in India and UK, including a continuous six-month period of study in Bhopal (November 2010-April 2011). In terms of archival materials, the discussion draws on ICJB's organizational archives in Bhopal and those hosted online on its campaign website (bhopal.net), commemorative and public relations materials linked to the disaster hosted on websites maintained by Indian state agencies (bgtrrdmp.mp.gov.in/envn.htm) and the Union Carbide Corporation (bhopal.com), and online archives hosting documents linked to the legal proceedings around the disaster. In terms of participant observation, I took part in the commemorative activities organized by the ICJB around the anniversary of the disaster in Bhopal (December 2010) as well as other protest actions in India and the UK, and undertook interviews with movement leaders and survivors participating in these activities.

The article is structured as follows. I will first introduce the framework of politics of scale and the concepts of scale frames, counter-scale frames and memory-work which I will use to examine the dynamics of the contestation over the remembrance of Bhopal and the 
struggle for justice. Following that, I will situate the contribution that the paper makes to two key sets of literature: examinations of the transnational political mobilization of memory and the work on movements for justice in Bhopal. I will then embark on the discussion of the contestation over memory and justice between the Indian state and the transnational corporation, Union Carbide Corporation (UCC) on one side and ICJB on the other. I will first analyse the localising scale-frame generated by the 1989 judicial settlement between the state and the corporation and its stabilization and re-iteration in their commemorative activities. I will then discuss the ICJB's development of a counter-scale frame which challenged the localisation and re-scaled accountability and justice for the disaster across local, national and transnational scales. The discussion will conclude with a reflection on the value of deploying a politics of scale approach to the study of the memory contestations in particular those involving social movement organisations and transnational campaigns for justice.

\section{The politics of scale: scale frames and counter-scale frames}

The literature on 'politics of scale' emerges from the work of political and human geographers trying to explain the mechanisms through which global capitalism stabilized unequal power relations. Within this context 'scales' refer to the 'modality of hierarchization and rehierarchization through which processes of socio-spatial differentiation unfold both materially and discursively' (Brenner 2001, 600). While early formulations from within the political economy tradition tended to view scales as a relatively fixed nested hierarchy imposed on social actors and social processes, more recent social constructionist approaches have emphasised scales as being produced and transformed through processes of social interaction (Marston 2000; Gonzalez 2006; Engels 2015). This paper works with a social constructionist approach to the politics of scale, examining it as a contestation between different actors and institutions as they participate in the process of linking a particular social 
situation to a particular spatial scale (local, national, transnational) in order to gain power and authority (Swyngedouw 2004). Scaling or scale-production within this conceptualisation encompasses both the process of framing conceptions of reality or 'scales of meaning' and the process of linking them to distinct decision making bodies or 'scales of regulation' (Towers 2000:26); the process of scaling therefore has both rhetorical and material consequences and scale framings are always under contestation and not necessarily enduring (Marston 2000).

For this paper, I will be using the concepts of scale frames and counter-scale frames as developed by Hilda Kurtz (2003) in her analysis of an 'environmental justice controversy' involving a community-based struggle against the building of a highly polluting chemical production facility in Convent, Louisiana. Scale frames, within her conceptualisation are 'the discursive practices that construct meaningful (and actionable) linkages between the scale at which a social problem is experienced and the scale(s) at which it could be politically addressed or resolved' (894). Counter-scale frames on the other hand are 'discursive strategies directed at undermining one or more elements of the scale-oriented collective action frames' (896). The concept of scale frames is particularly useful for the study of the scaling practices of social movement actors as it combines a 'collective action frames' perspective (Snow and Benford 1988 cited in Kurtz 2003) with an attention to the politics of scale. Furthermore, the concept of scale-frames manages to encompass the two analytically distinct aspects of scaling, 'scales of meaning' and 'scales of regulation', which are intimately interconnected in the practice of contentious politics. Using this framework of the deployment of scale frames and counter-scale frames, I will be analyzing the back and forth political struggle between the ICJB, the Indian state and the corporation over the nature of the injuries caused by the Bhopal disaster and the appropriate forum for their redress. 


\section{Scaling in memory-work: grounding the dynamics of transnationalising memory}

While Kurtz's (2003) case study examines the contestation over the framing of potential problems to be caused by the setting up of a polluting unit, the focus of this paper is ICJB's campaign in Bhopal to re-frame events from the past; in this context, the remembrance of the disaster emerges as a crucial site for the construction of new scalar connections in narratives and performances. This discussion therefore brings the politics of scale framework to bear on the field of 'memory-work', what Annette Kuhn $(2002,157)$ describes as 'a conscious and powerful performance of memory... an inquiring attitude towards the past and its (re)construction through memory; it calls into question the transparency of what is remembered; and it takes what is remembered as material for interpretation'. In this paper, the memory-work to be examined deals primarily with the commemorative discourses and performances produced by the ICJB around the anniversary of the disaster.

The concepts of the politics of scale and scaling have only recently been brought to bear on discussion of memory (De Cesari \& Rigney 2014; Kennedy \& Nugent 2016). This has accompanied calls for the development of new critical approaches to the burgeoning study of transnational movements of memory (Radstone 2011; Amine \& Beschea-Fache 2012; Bisht 2013; De Cesari \& Rigney 2014). The concept of transnational memory has recently seen a surge of interest in memory studies as the field has shifted its focus from stable and canonized mnemonic sites, practices and objects within the traditional container of the nation state to the dynamics of 'mnemonic processes unfolding across and beyond borders' (Erll 2011, 9). While this shift has produced rich accounts of memory's flows, there has been a tendency to take memory's fluidity for granted (De Cesari and Rigney 2014); insufficient attention has been paid to actors and labour involved (Bisht 2013) as well as the specific places, times and uneven material conditions in which the transnational mobilisation, circulation and articulation of cultural memory is grounded (Radstone 2011). Furthermore, 
these insufficiently contextualised macro-level discussions of memory's travel have resulted in formulations advancing a binary and essentialised pitting of the local against the transnational and a normative valorisation of the latter (Amine \& Beschea-Fasche 2012); this tendency has been particularly problematic in relation to discussion of memory and justice. Recent discussions of the relationship between memory and justice have presented celebratory accounts of the emergence of a mediatised cosmopolitan memory (see Levy \& Sznaider 2002, 2005, 2010) which can be mobilised by traditionally dis-empowered actors in circumventing the national scale and pursuing justice at transnational forums; however insufficient attention has been paid to the specific contexts of such mobilisations, the actors and labour involved, and the inequalities characterising the field.

In this context, De Cesari \& Rigney (2014) have called for a 'questioning of the unspoken hierarchies of scale implicit' in research on memory and the development of approaches that 'allow us to grasp the multi-scalarity of social-cultural processes and the fundamental "mutual construction of the local, national and global" in the contemporary world (Glick Schiller 23)' (5; italics in the original). This paper contributes to the development of such an approach by demonstrating the utility of the concepts of scaling, scale frames and the framework of politics of scale to the analysis of transnational memory contestation. These concepts keep the focus firmly on the work done by social actors as they engage in a contestation over the strategic construction of scalar linkages in their discursive and performative remembrance. The approach thereby avoids reification of different scales of memory revealing instead their processual and contextual constitution in the interaction of different agents of memory.

This grounded, actor-centred, politics of scale approach thereby has the potential of significantly advancing understanding of the imbrication of memory and justice: 'the centrality of memory to processes of law, adjudication and justice, and to the national and 
transnational projects these processes support' (Kennedy \& Nugent 2016:65). It facilitates a more critical account of the connective work required for transnational mobilisations of memory, avoids reifying and valorising forms of transnational remembrance, and refocuses attention on the challenges and inequalities encountered, in particular, by structurally disempowered actors such as social movement organisations from the Global South.

Bhopal as a case for analysis within this framework is particularly productive as it addresses the paucity of non-western, non Euro-centric examinations of memory and brings into view the work of a neglected set of memory actors; social movement organisations have been largely excluded from the analysis of memory contestations as the focus has remained firmly on state actors, national communities or on traditionally recognised sub-national groupings defined by categories such as ethnicity, religion and race (see Gongaware 2009; Zamponi 2013; Kubal \& Beccera 2014). This study contributes to calls for recognising and examining social movements as 'mnemonic agents in the public arena' and more specifically for an investigation into the 'limits' to this memory-work (Zamponi 2013: 3).

\section{Politics of scale in Bhopal: focussing on the scalar practices of social movement organisations}

The politics of scale approach also adds to the literature on the movement for justice in Bhopal. Recent assessments of the social movement in Bhopal have tried categorizing the different organisations according to their different 'militant particularisms', the different higher level 'abstractions' guiding their praxes (Mukherjee 2010; Scandrett \& Mukherjee 2011). In these analyses, ICJB has been assigned an 'environmental justice' abstraction as opposed to the Bhopal Gas Peedit Mahila Udyog Sanagathan (Bhopal Gas Affected Women Workers' Campaign), the other significant group with mass membership, which is seen as operating within a 'class struggle' orientation (Scandrett \& Mukherjee: 2011). While this 
body of work has been useful in terms of providing a mapping of the range of different discourses and collective identities being mobilized by SMOs in Bhopal, there is a tendency to present these 'abstractions' as stable categories, which explain the actions of the groups, rather than viewing them as evolving constructions attempting to seek solutions for problems, in this case the problem of achieving justice for Bhopal (see MacSheoin 2014). What is consequently lost from view is the contestations over power to which these framings are responding, the strategic advantage they afford in terms of demanding justice, and the discursive, material and performative work that is required to stabilise and legitimise them. Examining the ICJB's work in Bhopal through the politics of scale framework allows us to avoid the reification of the environmental justice frame and focus attention on the scalar practices of social movement actors; this paper will reveal how the ICJB's mobilisation of an environmental justice framework has to be understood as responding to the localisation of the scales of meaning and regulation generated by the memory-work of the Indian state and UCC.

In the next section, I begin with a short overview of the localising scale frame imposed by the legal settlement negotiated between the Indian state and the corporation. I discuss how this settlement reduced the meaning of the disaster to the undeserved suffering of abstract victims, limited justice to the provision of immediate relief and the scale of regulation to local state administration. Most SMOs working in Bhopal accepted this scale frame of undeserved human suffering to be alleviated by the welfare state and limited their activities to pursuing greater financial compensation and better medical care for the gas survivors from the local state. I will demonstrate how the ICJB attempted to develop a new scale frame, or more appropriately a counter-scale frame, of a second/ongoing poisoning linked to environmental contamination, which allowed for the expansion of accountability and justice across the local, national and transnational scales. This rescaling will be discussed in relation to memory-work carried out by the ICJB focussing in particular on the 
commemorative discourses and performances around the anniversary of the event.

\section{The May 1989 settlement and the localising scale-frame: human suffering and the welfare state}

In the aftermath of the disaster, in March 1985, the Government of India (GoI) legislated the Bhopal Act consolidating all claims arising out of the Bhopal disaster and making itself the only competent authority on the basis of the parens patriae function of the state to represent the victims (Muralidhar 2004). The GoI then pursued the case in the New York District Court of Judge Keenan who ruled that US courts were not the appropriate forum for redress and bound the Union Carbide Corporation (UCC) to the jurisdiction of the Indian courts. The case then moved through the Indian courts till it arrived before the Supreme Court of India (SC), the highest judicial forum in India. In May 1989, the SC announced a settlement of 470 million dollars between GoI and UCC. The survivors or their representatives were not involved in the negotiations and their consent was not obtained. The individual compensation claims of the survivors were to be dispensed in accordance with an administrative scheme laid out in the Bhopal Act (Muralidhar 2004). The victims were not entitled to a particular amount of compensation; they had to argue their case and prove their injuries before a system of special courts in Bhopal supervised by local welfare commissioners operating under the Indian State's Department of Chemicals and Petrochemicals, Ministry of Chemicals and Fertilizers. The primary justification provided for the settlement by the court was the 'tremendous suffering of thousands of persons' and the need for 'immediate relief', which could not be 'subordinated to the uncertain promises of the law' (UCC v. UoI, 1989).

This brief description of the legal process that followed the disaster serves to demonstrate the extraordinary shift in scales of meaning and regulation of the disaster in the court's ruling and how this shift was accompanied by disempowerment of survivors. The 
move away from a transnational scale to a welfare bureaucracy located at the local scale was legitimised by the scale frame of the need for providing immediate relief for the tremendous suffering of the people. The suffering of the victims allowed the judiciary to produce a 'verbal discourse' that legitimized 'the government as the guardian of the people, and the judiciary as the protector of the rule of law' (Das 1995, 159). Not only had the court failed to fix responsibility for the disaster it had also allowed the corporation the possibility to represent the settlement as aid and a humanitarian gesture rather than an acknowledgement of transnational liability (UCC 2017a); it is on the basis of this settlement that the UCC can claim that it 'has never been found liable or responsible for damages by any court' (UCC 2017a) and maintain its official position that the disaster was caused by employee sabotage not faulty design or operation (UCC 2017b). The scaling established by the 1989 settlement has been re-iterated in many subsequent Supreme Court rulings $(1991,2007)$ and was institutionally stabilised by the establishment of the bureaucratic system envisioned in the judgement (End Note 1).

\section{Commemorative (re) iteration of localising scale frame by the state and corporation}

While the scale frame was most powerfully stabilised in the subjection of gas survivors to the processes and institutions established by the court's ruling, a brief examination of its commemorative iteration in the memory-work carried out by the state and the corporation is necessary in the context of the paper's analytical concerns. In keeping with the spatial localisation of the meaning of the disaster, no national level commemoration, in terms of a memorial or a national day of remembrance, was instituted. All commemorative discourse and performance was issued and organised at the local level by the Bhopal Gas Tragedy Relief and Rehabilitation Department (BGTRRD), an agency of the local government based in Bhopal. No formal memorial for the disaster has been constructed by the local government. 
In keeping with the narrative of the disaster being about the welfare state alleviating the suffering of the survivors by providing relief, spaces of rehabilitation such as hospitals and vocational training centres built for the use of the survivor community have been discursively framed as memorial spaces. These are ritually visited by the minister-in-charge of the BGTRRD on the anniversary of the disaster and this performance is pictorially re-inscribed in an annual commemorative publication and on a local government website (www.bgtrrd.mp.gov.in; BGTRRD 2017a). Both the publication and the website, present a rigorously stable narrative of the disaster including sections on the 'the tragedy', 'the aftermath' and 'the state takes over', followed by descriptions of various rehabilitation programs (BGTRRD 2017b). The narrative of the 'tragedy' ascribes no causal responsibility for the accident to any party, naturalising it as a physical event that occurred due to a 'chemical reaction' (BGTRRD 2017b). The uniqueness of the event is limited to the 'enormity' of the immediate suffering caused, which in turn is used to justify the inadequacy of the state's response in the immediate aftermath. Having dealt with the event of the disaster and its aftermath in this cursory and decontextualized manner, the majority of the narrative is taken up celebrating the success of the local state's 'special administrative machinery' in providing relief and rehabilitation, concluding in the definitive claim that 'the gloom of despondency which hung over the poison-gas disaster area like a pall has now lifted' (BGTRRD 2017b).

Union Carbide Corporation's (UCC) affirmation of the scale frame imposed by the 1989 judicial ruling can be clearly located in the Bhopal.com website, that it maintains. The site presents itself as a 'Bhopal Information Centre', underscores the fact that UCC was never held liable for the disaster, highlights the corporations provision of 'immediate and continuing aid' to the victims, and emphasizes the 'settlement of all claims' arising from the event in accordance with 1989 judicial ruling. UCC also denies any liability for claims of 
groundwater and soil contamination in Bhopal indicating that all responsibility for the cleanup of the factory site lay with the local government who had issued the company a clean chit when repossessing the land in 1998 (UCC 2017c). While contesting all points of specific and actionable linkages between the parent multinational company and the suffering in Bhopal, UCC emphasises its participation in a 'moral' remembrance of the disaster by the chemicals industry as a whole; a link is provided to the webpage of the 'Responsible Care' program, a global industry-wide initiative involving voluntary efforts to improve 'process safety standards, community awareness and emergency preparedness' to prevent the occurrence of disasters like Bhopal (UCC 2017a). The Dow Chemical Company (hereafter Dow Chemical) which bought UCC in 2001 (End Note 2), on its part, also identifies the local government in India as being responsible for the factory site and highlights that it "never owned or operated the plant' and therefore bears 'no responsibility for Bhopal' (Dow Chemical 2017). Like UCC, it also however prominently claims a moral remembrance of Bhopal through its participation in the 'Responsible Care' program (Dow Chemical 2017).

In the memory-work carried out by both the state and the corporations, we can clearly see the attempt to maintain the legitimacy of the localising scale frame imposed by the 1989 judicial settlement in order to legitimise their own positions. The local government emphasises the successful nature of the rehabilitation and relief programme undertaken to reaffirm the conceptualisation of the welfare state capable of addressing the suffering of its citizens. The corporations affirm the local scaling primarily to maintain their denial of any liability for the event, emphasize the moral nature of their humanitarian response to the suffering of the victims and extend it further to the entire chemicals industry in terms of an institutionalised program of ensuring better safety and environmental standards. In the next section, we will see how the ICJB attempted to counter this localisation in scaling and the kind of memory-work this contestation required. 


\section{ICJB and the counter scale frame: the second/ongoing poisoning}

The movement for justice in Bhopal is one of the longest running struggles for justice anywhere in the world. There are several different groups operating in Bhopal that represent the survivors of the disaster. This paper concentrates on the ICJB, a coalition constituted primarily by four gas survivor organisations Bhopal Gas Peedit Mahila Stationery Karmchari Sangh (Bhopal Gas Affected Women Stationery Workers' Union), Bhopal Gas Peedit Mahila Purush Sangharsh Morcha (Bhopal Gas Affected Women and Men's Struggle Front), Bhopal Gas Peedit Nirashrit Pension Bhogi Sangharsh Morcha (Bhopal Gas Affected Destitute Pensioners' Struggle Front), Children Against Dow-Carbide and the solidarity group, Bhopal Group for Information and Action (BGIA) (End Note 3). The group is further connected to affiliates across India and other parts of the world, in particular student groups in universities across the United States. It has also been supported by Greenpeace and Amnesty International in some of its key actions (Zavestoski 2009; MacSheoin 2012, 2015).

ICJB's formal consolidation took place in the period between the mid-1990s and early 2000s precisely when Union Carbide Corporation (UCC) sought to reinforce the localisation of the disaster by eliminating itself entirely from the circuits of liability for Bhopal, initially through the sale of its Indian subsidiary and then its acquisition by Dow Chemicals in 2001. Most survivor groups in Bhopal, lacking the capacity and resources to challenge the regulatory localisation effected by the state and the corporation, were forced into a narrowing of their collective action frames to focus primarily on pursuing justice at the level of local administrative machinery and occasionally, at national judicial forums; in effect, while these groups persisted in emphasising the continuing suffering of the survivors and the unfairness of the financial settlement, they were compelled to operate within the localising scale-frame of the welfare state (End Note 4). The ICJB, by contrast, aided in particular by the scientific 
and communicative expertise of the educated middle class activists from the Bhopal Group for Information \& Action (BGIA), was able to seek ways of utilizing the political opportunities presented by the UCC-Dow Chemical merger to challenge the localising scaleframe imposed by the judicial settlement (Zavestoski 2009). It did so by developing a counter scale frame of the 'second/ongoing poisoning' (BGIA \& BMA 2012, 60) which sought to expand both the symbolic meaning of the disaster and multiply the regulatory forums for seeking justice.

The counter scale frame of 'the second/ongoing poisoning' drew attention to the issue of soil and groundwater contamination experienced by communities living around the site of the UCC plant; this was an entirely new set of injuries not covered by 1989 judicial ruling and therefore created opportunities for disrupting the regulatory and memorial localisation of the disaster. ICJB argued that UCC knowingly followed unsafe waste-disposal practices in its operation of the factory before the leak and left behind a contaminated site full of toxic waste after the leak. While there was some knowledge of the contamination issue in Bhopal before the late 1990s, it was ICJB's intensive work during this period, building partnerships with transnational anti-toxics advocacy campaigns that made the development of the new scaleframe possible. In particular, its partnership with Greenpeace between 1999 and 2004 was vital in securing scientific and communicative expertise required to collect and mobilise evidence supporting the narrative of the 'second poisoning' (see Mac Sheoin 2012 for a detailed account of this partnership). A 1999 report by Greenpeace, 'The Bhopal Legacy', published results of tests on soil and groundwater samples in and around the factory site and confirmed the presence of heavy concentrations of carcinogenic metals and heavy metals (Greenpeace 1999) and on December 2, 1999, the fifteenth anniversary of the disaster, Greenpeace declared the old Union Carbide factory site in Bhopal 'a global toxic hot' (BGIA \& BMA 2012: 89). Beginning in 1999, ICJB with the support of partners like Greenpeace 
sought to mobilise this new scale-frame of the 'second/ongoing poisoning' to engage in challenging the localisation of the disaster in the inter-linked domains of justice and memory.

The deployment of this new scale frame allows the ICJB to construct the narrative of a 'second/ongoing disaster' connected to but distinct from the first disaster, the 1984 gas leak (BGIA \& BMA 2012, 60; ICJB 2017). While the population affected by this 'second disaster' includes some victims of the 1984 gas leak, most are poor families which moved into slum colonies that sprung up on the unoccupied land around the factory site after the leak; ICJB identifies this new constituency of victims of water poisoning as water victims (paani-peedit). This new group of victims is suffering from several health issues, exhibiting in particular, very high incidence of congenital disorders in new-born children (BGIA \& BMA 2012: 156). The ICJB is the only organisation working in Bhopal that has taken up the issue of the provision of justice for these new set of injuries and the new constituency of victims of water contamination. In the next section, employing a politics of scale approach, I examine how the ICJB mobilising the scale-frame of the 'second/ongoing poisoning' developed a multi-scalar conceptualisation of justice (local, national, transnational) for Bhopal and the accompanying strategies for communicating and stabilising this expansion in their judicial activism and their commemorative memory-work.

\section{Beyond the local: restoring transnational connections and demanding multi-scalar justice}

The first mobilisation of the counter scale frame has been to restore the transnational connections of the disaster in particular the culpability of the transnational corporation for the Bhopal. While Union Carbide Corporation (UCC) had sought to erase itself completely from the circuits of accountability, the ICJB using the counter scale frame of the 'second poisoning' successfully made re-visible the transnational corporate connection both in the judicial/regulatory domain and in the field of commemorative memory-work. Emphasising 
the 'ongoing' nature of the disaster also challenged the temporal localisation of the event to the 1984 gas leak. Since the new contamination related injuries were not a part of the 1989 settlement, ICJB initiated legal action against UCC in US courts filing multiple cases in 1999, $2004 \& 2007$ for 'environmental harm' caused by groundwater contamination (Muralidhar 2004: 75; UCC 2017d). During these legal proceedings as part of the 'discovery' process UCC was forced to disclose internal documents which clearly demonstrated the corporation's awareness of high levels of toxic contamination within the factory site as well as the incompetence of the agency tasked with carrying out the site's toxicity assessment for the Indian state (ICJB 2002). Despite these revelations, UCC's argument that the site had been handed back to the local state government which now bore all 'accountability for the site' (UCC 2017e) held sway; the court cases were argued over several years and went through several rounds of appeals, all were ultimately dismissed, the last in August 2016 (UCC 2017d).

Despite the failure to secure accountability in the legal domain, the process of being able to call UCC/Dow Chemical to account in a US judicial forum and secure incriminating evidence was a big symbolic victory that was mobilised in other political domains, most significantly that of the commemoration of the disaster; the restoration of the linkage between Bhopal and UCC/Dow Chemical through the legal process in the US lent legitimacy to the narrative of their culpability in the domain of social memory both locally in Bhopal and transnationally. The narrative of the 'second/ongoing poisoning' and the symbolic restoration of the link to UCC/Dow Chemical allowed ICJB to reposition Bhopal as an ongoing toxic disaster with global implications and connect it to a longer history of other toxic disasters linked to Dow Chemicals; this re-framing was concretised in the adoption of the campaign slogans 'No More Bhopals' and 'We All Live in Bhopal' starting with the fifteenth anniversary of the disaster in 1999 (see Zavestoksi 2009). These slogans perfectly 
encapsulate ICJB's explicit and strategic challenging of the spatial, temporal and symbolic localisation of Bhopal by the state and the corporations. The narrative of the continuing responsibility of UCC/Dow Chemicals for Bhopal has been legitimised and approved in a host of transnational forums including the awarding of the 2004 Goldman Environmental Prize to two female ICJB activists from Bhopal for their campaigning against toxic contamination (Goldman Environmental Foundation 2017) and ICJB's more recent success in stirring controversy and forcing the removal of Dow Chemicals' branding from the 2012 London Olympics stadium (see Botelho \& Zavestoski 2014; Shields, Laurendeau \& Adams 2016 for a discussion of ICJB's Olympics campaign).

The second mobilisation of the counter scale-frame has been to resituate the injustices caused by the disaster as having emerged from processes occurring at the 'intersection of scales' (see Fraser 2010). The new scale-frame of the 'second/ongoing poisoning' is not used to seek accountability exclusively at any one particular scale; it instead directs attention to the intersection of scales (local, national, transnational), making specific but simultaneous, multiple and relational demands of actors located at each scale. Each articulation of these demands is also a performance of memory work as the past is reinterpreted to draw connections between the first (gas-leak) and the second disaster (soil and water contamination) and the ongoing suffering from both. This multi-scalar reframing of accountability requires articulation in different forms of memory-work posing different levels of creative challenges.

It is relatively straightforward to present the multi-scalar framing in an anniversary press note or on the campaign wesbites; the list of demands produced for the $30^{\text {th }}$ anniversary of the disaster for instance systematically outlines four sets of demands targeted at the transnational corporations (UCC/Dow Chemical), the Government of USA, the Government of India (national state) and the Government of Madhya Pradesh (local state) (ICJB 2014). 
UCC/Dow Chemical are required to pay additional financial compensation for the continuing injuries caused first disaster (gas leak), for the decontamination of the factory site and for the injuries caused by the second disaster; they are also required to subject themselves to the jurisdiction of local and national courts in India. The Government of USA are required to 'acknowledge and express regret' for supporting the construction of the UCC plant and their role in hindering judicial proceedings linked to the gas leak. The Government of India are required to support court ICJB's judicial interventions at national and transnational forums, stop Dow Chemicals from investing in India, and investigate the contamination in Bhopal. The Government of Madhya Pradesh are required to support ICJB's judicial campaign for clean-up of the site, ensure better hospital care for survivors and expand free medical care access to victims of the second disaster (see ICJB 2014 for full list of demands). The demands maintain both the distinction and the connection between the first and the second disaster. They seek to use different regulatory powers located at different scales to address the same issues in different ways; the justice conceptualized in the demands is both multidimensional and multi-scalar. Translating this complex conceptualization into an effective commemorative performance is however a challenging task requiring creative memory work. In the next section, I examine how the ICJB negotiates these challenges in the design of the commemorative performances around the annually staged anniversary of the disaster.

\section{Performing a multi-scalar remembrance in anniversary commemoration}

The anniversary of the disaster on December $2^{\text {nd }}$ and $3^{\text {rd }}$ sees the most concentrated commemorative activity. The ICJB being an international network, there are often a host of small events around the world coordinated by affiliated groups; it is however the performances that take place in Bhopal, participated in and directly coordinated by the ICJB 
that are recognized as the key memorial texts and extensively circulated in the local, national and international media. The primary problem faced by the ICJB in enacting multi-scalar accountability in performance were the limits posed by the memory of earlier protests and commemorations which clearly defined the disaster in terms of the original gas leak and afforded no space for inclusion of the second disaster of the water contamination. The existing template of memorial performances was focused on a retributive enactment of anger directed against the figure of Warren Anderson, the American Chief Executive Officer of UCC at the time of the 1984 leak. The burning of effigies of Anderson/UCC outside the space of the Bhopal factory became the central ritual in the years following the immediate aftermath of the disaster. Much of the anger was directed against the space of the factory, both as the source of the lethal gas and as the property of the guilty corporation. After the 1989 settlement and the subsequent failure of legal attempts to overturn it, the effigy burning was viewed as a 'negative' gesture; a desperate performance of violence that expressed the dissatisfaction of the gas survivors with all representation and articulated their 'desire not to be represented' (Fortun 2001:170).

The ICJB negotiated a symbolic expansion by devising a commemorative performance which was based on the template of the original protests but added and updated elements to illustrate an understanding of injustice occurring at the intersection of multiple scales. The most powerful way in which it did this was by expanding the effigy beyond the simple personalization of Anderson or UCC to the representation of relationships of oppression. The effigy used in the 2010 protest (Figure 1) is a perfect example of this relational representation. 


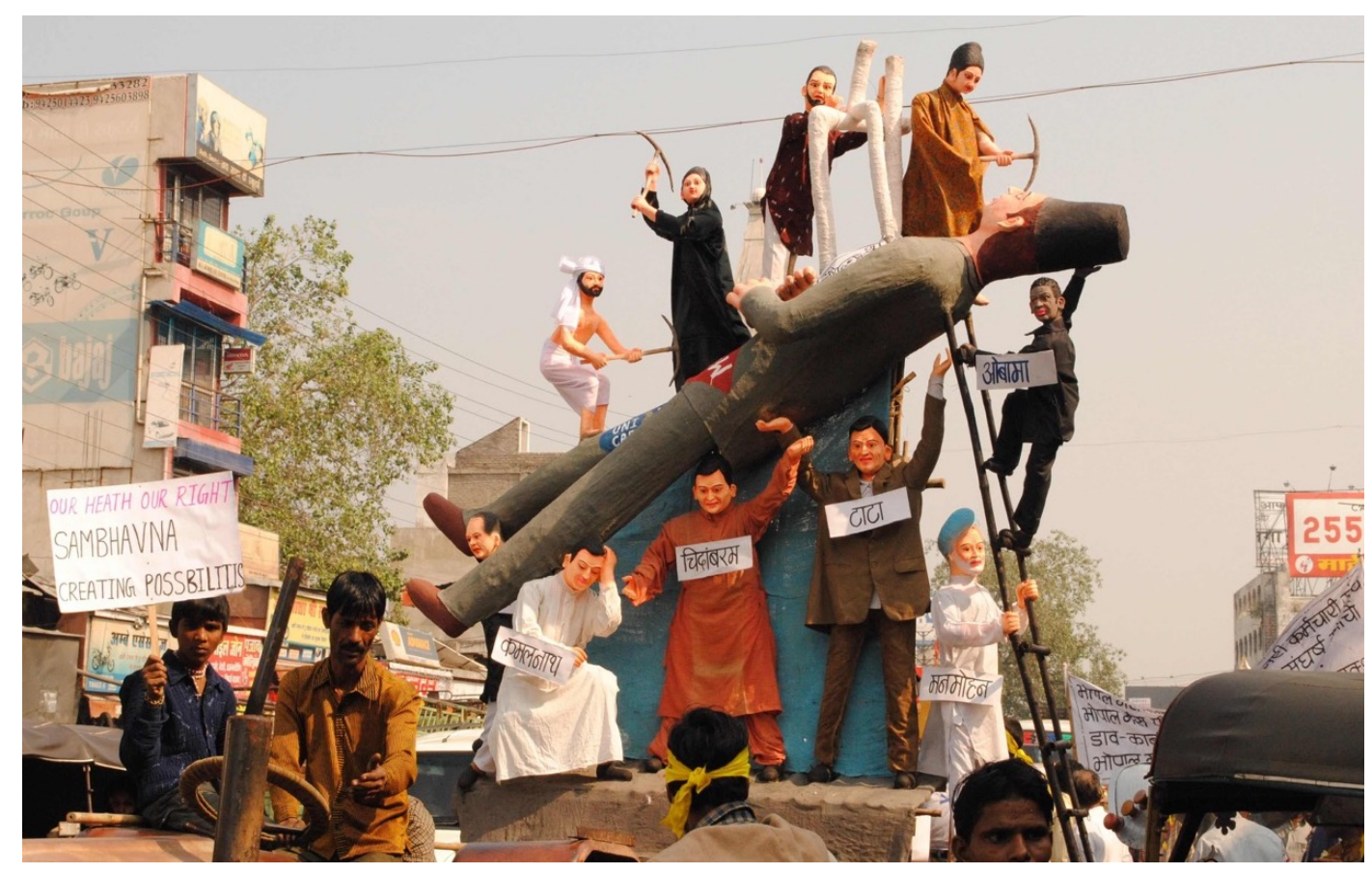

Figure 1. Dow-Carbide effigy from the ICJB protest march organised as part of the $26^{\text {th }}$ anniversary of Bhopal disaster on $3^{\text {rd }}$ December 2010. Copyright-Author.

The effigy pictures the Government of India (represented by the figures of Prime Minister Manmohan Singh and other cabinet ministers), the Government of USA (represented by the figure of President Obama), Indian multinational corporations and Indian judiciary trying to support the prone figure of UCC/Dow Chemical as it is confronted by the diverse community of gas survivors. This representation foregrounds the collusive relationship between different scales of government, national judiciary, and transnational corporations based in India and the US, effectively portraying the injustices as lying across scales. Similar relational representations have been used on other anniversaries. Other elements of the performance such as the slogans are also updated to include the category of the 'paani peedit' (water-victims). The attempt is to make the memorial performance meaningful to the expanded constituency of victims represented by the ICJB thereby also 
expanding the scale of local support for the movement for justice. This relational representation is not only effective at the local scale but is also meaningful to audiences at other scales and re-mediated successfully across different scales by the use of campaign website (Bhopal.net).

The other strategy of distributive scaling is the multiplication of commemorative events. While other survivor groups typically organize one memorial event, the ICJB has evolved a set of activities spread out over the period of the week leading up to the anniversary. Most prominently these include an awards function honoring women activists leading campaigns against corporate crime or environmental pollution, a press conference disseminating information on the medical condition of gas and water victims treated at an affiliated medical clinic, and an event featuring poetry recitals by local poets on the event of the original leak. All of these occasions serve as the site for addressing different dimensions of the disaster and targeting specific scales. All activities are remediated on the campaign's website (Bhopal.net) which allow for the assemblage of events to be rendered coherent again by the narrative of the two linked and continuing disasters.

This discussion has demonstrated how the ICJB embedded relational representations in its commemorative performances and discursive memory-work to reassert the multiscalarity of the Bhopal disaster and challenge the localized settlement imposed by the state and the corporations. In the conclusion, I briefly reflect on the implications of this case-study on the utility of employing a politics of scale framework to examine the domains of memory and justice.

\section{Conclusion}

This paper employed the politics of scale approach and the concept of scale-frames and counter-scale frames to examine the contestation over memory and justice for Bhopal. The 
discussion revealed how the 1989 judicial settlement between the Indian state and Union Carbide Corporation developed the localising scale frame of 'tremendous human suffering' and the need for 'immediate relief' to decontextualize the disaster and remove all ascription of transnational corporate liability and state collusion. The disaster was thereby localized both in terms of its meaning and in terms of the scale of regulation to the issue of providing relief and rehabilitation at the local level within the framework of a benevolent welfare state; this localising scale frame was re-iterated and stabilized in the commemorative domain by the state and the corporation. ICJB undertook the disruption of this localisation by the mobilization of the counter-scale frame of the 'second/ongoing poisoning' which brought attention to the issue of toxic contamination of water and soil around the factory site and a new set of injuries and victims. This counter-scale frame was deployed to restore the transnational corporate connection in both judicial and memorial domains, re-establishing Bhopal as an ongoing globally relevant environmental disaster connected to a larger transnational memory of corporate toxic crimes. Crucially, the counter-scale frame also facilitated the formulation of multi-scalar accountability and justice for Bhopal, targeting state and corporate actors at local, national and transnational scales. Relational representations portraying relationships of oppression, in particular the collusion between national state and transnational corporations, were mobilized in the anniversary remembrance to communicate multi-scalar accountability in the commemorative domain.

At a broad level, bringing the politics of scale approach to the examination of memory politics helps address demands for a focus on the work of the agents of memory and the contextual construction of scalar linkages in discussions of transnational movements of memory (De Cesari \& Rigney 2014). More specifically, the politics of scale approach and the concept of scale-frames helps focus attention on the mutual construction of scales of meaning and scales of regulation providing a sharper analytical lens to examine the movements 
between the domains of memory and institutional justice (Kennedy and Nugent 2016). ICJB's work in restoring the transnational corporate connection and establishing multi-scalar accountability for the disaster required concurrent and linked interventions involving discursive and symbolic connection making between scales in the judicial and the memorial domains; expertise and symbolic materials moved in a fluid fashion between the two domains. The discussion crucially revealed that success in the ascription of culpability can be achieved within the domain of public memory despite the lack of success in courts and that this symbolic success can subsequently be mobilized in other non-judicial institutional forums. ICJB, in this regard, presents an encouraging example of the ability of social movement organisations from the Global South to challenge the memory-work undertaken by transnational corporations, which often remains hidden from view, limited either to the specialized domain of law, or effected through the spectacular and decontextualizing domains of advertising and public relations events (see Shields, Laurendeau \& Adams 2016). Finally, in relation to social movements and memory-work, ICJB's example reveals that SMOs can engage in creative interpretations of the past but that this work is limited by "pathdependency'. ICJB had to work within the framework of existing memorial performances to communicate a more complex relational narrative linking the first and second disasters and actors located across national and transnational scales.

The movement in Bhopal is an unfinished project. The quest for justice and the evolution of strategies to ensure its deliverance continues. In successfully re-connecting UCC/Dow Chemical with the call for 'No More Bhopals' and highlighting the collusion of national and local state actors, the commemorative work of the ICJB can be seen as a site for the imagination of 'alternate futures' (Baxi 2010:44). In the ways identified above, the politics of scale approach provides the possibility of a more critical mapping of the opportunities and constraints characterising the work of social movements as they engage in 
the transnational mobilisations of memory in the pursuit of justice against such powerful actors.

\section{Notes}

1. In 2010, following public uproar in India over the insufficiency of the punishment in the criminal case linked to the disaster, the Government of India was forced to file a curative petition in the Supreme Court of India seeking payments from UCC for the enhancement of financial compensation to the gas survivors and for the clean-up of the contaminated site. These cases continue to languish in court; the Indian state at both the national and the local level has demonstrated no desire to pursue the overturning of the 1989 settlement. UCC and The Dow Chemical Company on their part continue to refer back to the 1989 settlement as being the 'final determination' of liability for the disaster and indicate that the liability for the clean-up lies with the local state (see UCC 2017f). The collusion of the state and the corporation in the judicial localisation of the disaster therefore persists despite the filing of the curative petition.

2. The Dow Chemical Company acquired Union Carbide Corporation (UCC) in 2001. UCC remains a separate company, but its stock now is fully owned by The Dow Chemical Company.

3. Other survivors group including the Bhopal Gas Peedit Mahila Udyog Sangathan (Bhopal Gas Affected Women Workers' Campaign) have been a part of the ICJB but their participation has been limited and sporadic. The groups identified here have been a part of the coalition most consistently over the period of its existence and continue to operate as part of it at the time of writing. MacSheoin (2014) provides a comprehensive historical account of the dynamics of coalition building involving local organisations in Bhopal and transnational advocacy networks. The specific histories of local organisations working in Bhopal (including the constituents of the ICJB) can be accessed in Bhopal Survivors Speak (Bhopal Survivors Movement Study 2009).

4. Amongst the other groups operating actively in Bhopal, the Bhopal Gas Peedit Mahila Udyog Sangathan (Bhopal Gas Affected Women Workers' Campaign) has at times collaborated with other social movements on a national scale. Unlike the ICJB however, their scalar connection making does not extend transnationally to the corporations and the Government of USA. The injuries of water victims and the issue of the second disaster also do not feature in their memorywork in a prominent and consistent manner. 


\section{References}

Amine, L. and C. Beschea-Fache. 2012. "Crossroads of Memory: Contexts, Agents, and Processes in a Global Age.” Culture, Theory and Critique. 53(2): 99-109. doi:

$10.1080 / 14735784.2012 .685580$

Baxi, U. 2010. "Writing About Impunity and Environment: the 'silver jubilee' of the Bhopal Catastrophe." Journal of Human Rights and the Environment 1 (1): 23-44. doi:

$10.4337 /$ jhre.2010.01.02

BGIA (Bhopal Group for Information and Action) \& BMA (Bhopal Medical Appeal). 2012. The Bhopal Marathon. Brighton: Author. http://bhopalmarathon.org/cryforbhopal/index.html BGTRRD (Bhopal Gas Tragedy Relief \& Rehabilitation Department). 2017a. "Photo Gallery". Accessed July 26 2017. http://bgtrrdmp.mp.gov.in/gallery.htm

BGTRRD (Bhopal Gas Tragedy Relief \& Rehabilitation Department). 2017b. "Bhopal Gas Tragedy Relief and Rehabilitation”. Accessed July 262016.

http://bgtrrdmp.mp.gov.in/profile.htm

Bisht, P. 2013. "The Politics of Cosmopolitan Memory." Media, Culture \& Society 35(1):1320. doi: $10.1177 / 0163443712464553$

Botelho, B. and S, Zavestoski. 2014. “All the World's a Stage: The Bhopal Movement's Transnational Organizing Strategies at the 2012 Olympic Games.” Social Justice 41 (1): 169185.

Brenner, N. 2001. "The limits to scale? Methodological Reflections on Social Structuration." Progress in Human Geography 25(4) (2001): 591-614. doi: 10.1191/030913201682688959

Das, V. (1995) Critical Events: An anthropological perspective on contemporary India. New Delhi: Oxford University Press

De Cesari, C. and A. Rigney. 2014. "Introduction." In Transnational Memory. Circulation, Articulation, Scales edited by De Cesari, C. \& A. Rigney, 1-23. Berlin: De Gruyter. 
Dow Chemicals (The Dow Chemical Company). 2017. "Bhopal”. Accessed July 26, 2017. http://www.dow.com/en-us/about-dow/issues-and-challenges/bhopal

Engels, B. 2015. "Contentious Politics of Scale: The Global Food Price Crisis and Local Protest in Burkina Faso.” Social Movement Studies, 14(2):180-194. doi:

$10.1080 / 14742837.2014 .921148$

Erll, A. 2011. "Travelling Memory." Parallax 17(4):4-18. doi:

$\underline{10.1080 / 13534645.2011 .605570}$

Fortun, K. (2001) Advocay After Bhopal: Environmentalism, Disaster, New Global Orders. Chicago: University of Chicago Press.

Fraser, N (2010) Injustice at Intersecting Scales: On 'Social Exclusion' and the 'Global Poor'. European Journal of Social Theory. 13(3) 363-371.

Goldman Environmental Foundation.2017. "Rashida Bee \& Champa Devi Shukla: 2004 Goldman Prize Recipient Asia”. Accessed July 26, 2017. http://www.goldmanprize.org/recipient/rashida-bee-champa-devi-shukla/

Gongaware, T.B. 2009. "Review Essay: Struggling Over Origins: Explorations of the Movement-Memory Nexus." Sociological Spectrum: Mid-South Sociological Association. 30(1):128-133. doi: $\underline{10.1080 / 02732170903340935}$

Gonzalez, S. 2006. "Scalar Narratives in Bilbao: A Cultural Politics of Scales Approach to the Study of Urban Policy." International Journal of Urban and Regional Research 30(4):83657. doi: 10.1111/j.1468-2427.2006.00693.x

ICJB. 2002. “Carbide's Poison Papers". Available at https://www.bhopal.net/old bhopal web/bhopalnet/poisonpapers.html

ICJB. 2017. "Contamination and the Ongoing Disaster: 1969-Present". Accessed July 26, 2017. https://www.bhopal.net/what-happened/contamination/

ICJB. 2014. “Our Demands”. Available at https://www.bhopal.net/our-demands/ Kennedy, R. and M. Nugent. 2016. "Scales of Memory: Reflections on an Emerging 
Concept." Australian Humanities Review 59: 61-76.

http://australianhumanitiesreview.org/wp-

content/uploads/2016/08/AHR59 Introduction1.pdf

Kubal, T. and R. Becerra. 2014. "Social Movements and Collective Memory.” Sociology Compass 8(6): 865-875. doi: 10.1111/soc4.12166

Kuhn, A. 2002. Family Secrets: Acts of Memory and Imagination. London: Verso.

Kurtz, H. 2003. "Scale Frames and Counter-Scale Frames: Constructing the Problem of Environmental Injustice.” Political Geography 22: 887-916. doi:

10.1016/j.polgeo.2003.09.001

Levy, D and Sznaider, N. (2010) Human Rights and Memory. Penn State University Press.

Mac Sheoin, T. 2012. "Power Imbalances and Claiming credit in coalition campaigns: Greenpeace and Bhopal.” Interface 4(2): 490-511

Mac Sheoin, T. 2014. "Internationalising the struggle for justice in Bhopal: balancing the local, national and transnational." Interface: a journal for and about social movements 6 (2): 103-129. http://www.interfacejournal.net/wordpress/wp-content/uploads/2014/12/Issue-6 2Mac-Sheoin.pdf

Mac Sheoin, T. 2015. Justice for Bhopal! And No More Bhopals! Three decades of national and international campaigning. Process Safety and Environmental Protection http://dx.doi.org/10.1016/j.psep.2015.01.008

Marston, S. A. 2000. "The social construction of scale". Progress in Human Geography 24 (2): 219-242.doi: https://doi.org/10.1191/030913200674086272

Mukherjee, S. 2010. Surviving Bhopal. Dancing Bodies, Written Texts, and Oral Testimonies of Women in the Wake of an Industrial Disaster. New York: Palgrave Macmillan.

Muralidhar. S. (2004). Unsettling Truths, Untold Tales. International Environmental Law Research Centre Working Paper. Accessible from, http://www.ielrc.org/content/w0405.pdf Radstone, S. 2011. "What Place Is This? Transcultural Memory and the Locations of Memory Studies.” Parallax. 17 (4): 109-123. doi: 10.1080/13534645.2011.605585 
Scandrett, E. and S. Mukherjee. 2011. "Globalisation and abstraction in the Bhopal survivors' movement." Interface: a journal for and about social movements 3 (1):195 - 209.

http://www.interfacejournal.net/wordpress/wp-content/uploads/2011/05/Interface-3-1Scandrett-and-Mukherjee.pdf

Shields, R., J. Laurendeau, C. Adams. 2016. "The Logic of Memory: 'Paroxysms of tears and joy' for the London Olympics and the Bhopal Disaster.” Memory Studies 1-17. doi:10.1177/1750698016638407

Swyngedouw, E. 2004. “Globalisation or 'Glocalisation'? Networks, Territories and Rescaling." Cambridge Review of International Affairs 17(1): 25-48. doi:

$10.1080 / 0955757042000203632$

Towers, G. 2000. “Applying the Political Geography of Scale: Grassroots Strategies and Environmental Justice.” The Professional Geographer 52(1): 23-36. doi: 10.1111/00330124.00202

UCC (Union Carbide Corporation) v. UoI (Union of India) (1989) 3 SCC 38. https://indiankanoon.org/doc/193898488/

UCC (Union Carbide Corporation). 2017a. “Union Carbide's Response Efforts to the Tragedy \& the Settlement”. Accessed July 26, 2017. http://www.bhopal.com/UCC-ResponseEfforts-to-Tragedy

UCC (Union Carbide Corporation). 2017b. "Cause of the Bhopal Tragedy". Accessed July 26, 2017. http://www.bhopal.com/Cause-of-Bhopal-Tragedy

UCC (Union Carbide Corporation). 2017c. "Environmental Studies of the Bhopal Plant Site". Accessed July 26, 2017. http://www.bhopal.com/Environmental-Studies-of-Bhopal-Plant$\underline{\text { Site }}$

UCC (Union Carbide Corporation). 2017d. "Bhopal Litigation in the U.S". Accessed July 26, 2017. http://www.bhopal.com/Bhopal-Litigation-in-the-US 
UCC (Union Carbide Corporation). 2017e. "Remediation (Clean Up) of the Bhopal Plant Site”. Accessed July 26, 2017. http://www.bhopal.com/Remediation-of-Bhopal-Plant-Site

UCC (Union Carbide Corporation). 2017f. "Curative Petition Regarding the 1989 Bhopal Settlement". Accessed July 26, 2017. http://www.bhopal.com/Bhopal-Litigation-inIndia/Curative\%20Petition

Zamponi, L. 2013. “Collective Memory \& Social Movements.” In The Wiley-Blackwell Encyclopedia of Social and Political Movements. Edited by Snow, D.A., Donatella della Porta, Bert Klandermans, and Doug McAdam. Blackwell Publishing.

Zavestoski, S. 2009. "The Struggle for Justice in Bhopal. A New/Old Breed of Transnational Social Movement." Global Social Policy 9(3): 383-407 